\title{
Pola Alih Tutur dalam Naskah Drama First Love Karya Inggrida Wisnu S.
}

\author{
Sri Puji Astuti \\ Fakultas Ilmu Budaya Universitas Diponegoro \\ sripujiastuti0116@gmail.com
}

\begin{abstract}
The purpose of this research is to describe the pattern of turn-taking and how to get the turn-taking contained in the drama of First Love by Inggrida Wismu S. This research is a qualitative descriptive study. Methods of data collection in this research is an observation method means that observe to the play script drama of First Love by Inggrida Wisnu S. the source of data obtained by online media. The data obtained in this research was a fragment of taking. Then, the data was analyzed by using the pattern of turn-taking. The results showed that the pattern of turn taking based on the closest adjacency pair contained in the drama of First Love script was (1) the question was followed by the answer, (2) greeting was followed by salam, (3) the call was followed by the answer, (4) farewell expression was followed by message, (5) ) praise was followed by refusing, (7) complain was followed by questioning, answering, offering, and refusing, (8) accusing was followed by refusing and admitting (9) the petition was followed by agreement, petition, suspension, petition, granting. As for turn-taking in the First Love drama by Inggrida Wisnu S used how to acquire, steal, create, continue, and seize.
\end{abstract}

Keywords: turn-taking, talking, speaker, and the interlocutor

\section{Intisari}

Tujuan penelitian ini adalah mendeskripsikan pola alih tutur dan cara memperoleh giliran bicara yang terdapat dalam naskah drama First love karya Inggrida Wismu S. Penelitian ini merupakan penelitian deskriptif kualitatif. Metode pengumpulan data dalam penelitian ini adalah metode simak yaitu menyimak naskah drama First Love karya Inggrida Wisnu S. Sumber data diperoleh melalui media online. Data yang diperoleh dalam penelitian ini berupa penggalan wacana percakapan. Selanjutnya data dianalisis dengan menggunakan pola alih tutur. Hasil penelitian menunjukkan bahwa pola alih tutur berdasarkan pasangan ujaran terdekat yang terdapat dalam naskah drama First Love adalah (1) pertanyaan diikuti jawaban, (2) salam diikuti salam, (3) panggilan diikuti, perintah, dan jawaban, (4) salam pisah diikuti pesan, (5) pujian diikuti penolakan, (6) menawari diikuti memuji dan menerima, (7) mengeluh diikuti bertanya, menjawab, menawari, dan menolak, (8) menuduh diikuti menolak dan mengakui (9) permohonan diikuti perjanjian, permohonan, penangguhan, permohonan, pengabulan. Adapun pengambilan giliran bicara dalam drama First Love karya Inggrida Wisnu $\mathrm{S}$ menggunakan cara memperoleh, mencuri, menciptakan, melanjutkan, dan merebut.

Kata kunci: alih tutur, tuturan, penutur, dan mitra tutur 


\section{PENDAHULUAN}

Dalam kehidupan sehari-hari kita tidak pernah terlepas dari komunikasi dengan orang lain. Komunikasi sendiri merupakan proses penyampaian pesan dari satu pihak ke pihak lain. Adapun pengertian komunikasi menurut Kamus Besar Bahasa Indonesia (2007:585) adalah pengiriman pesan atau berita antara dua orang atau lebih sehingga apa yang disampaikan dapat dipahami. Komunikasi dapat dilakukan secara lisan maupun secara tertulis. Contoh komunikasi tetulis misalnya surat- menyurat. Komunikasi lisan dapat berupa monolog, dialog, maupun polilog. Komunikasi secara lisan misalnya dalam drama.

Drama merupakan salah satu genre sastra. Drama menceritakan kisah kehidupan manusia yang ditampilkan dalam bentuk dialog yang dipentaskan. Hal tersebut sejalan dengan Suroso (2015:10) yang berpendapat bahwa persoalan yang dihadapi dalam naskah drama adalah konflik manusia yang tercernin dalam bentuk lakuan atau dialog. Lebih lanjut Suroso berpendapat bahwa tema dalam naskah drama biasanya diperoleh pengarang melalui kesaksian hidup, penggambaran realitas kehidupan, bahkan persoalan sosial, politik, dan budaya yang dialami pengarangnya.

Naskah drama First Love bercerita tentang kisah cinta pertama antara Dokter Nugi dan Suster Desca. Mereka bersahabat pada waktu masih kecil. Karena ayah Dokter Nugi harus pindah ke luar kota, akhirnya mereka berpisah. Pada saat mereka berpisah Nugi memberi Desca kalung. Setelah lima belas tahun berpisah, akhirnya mereka bertemu kembali di sebuah rumah sakit tempat mereka bekerja. Nugi sudah menjadi Dokter dan Desca menjadi suster.

Dalam naskah drama masing-masing tokoh mengungkapkan gagasannya melalui percakapan. Ketika antntartokoh dalam naskah drama ini beiinteraksi, tokoh dalam naskah drama ini diduga mengunakan pola alih tutur dan cara tokoh memperoleh giliran bicara. Hal ini terjadi karena dalam berinteraksi biasanya tokoh dalam naskah drama ini berbicara secara bergantian.

Berdasarkan latar belakang tersebut permasalahan yang dibahas dalam makalah ini adalah bagaimana pola alih tutur yang terdapat dalam naskah drama First love karya Ingrida Wisnu S. Tujuan penelitian ini adalah mendeskripsikan pola alih tutur dan cara memperoleh giliran bicara yang terdapat dalam naskah drama First Love karya Inggrida Wisnu S. 
Howe (dalam Rani, 2004:201) berpendapat bahwa peralihan tutur merupakan hal yang sangat penting dalam pecakapan. Peralihan tutur akan menimbulkan pergantian peran dalam percakapan. Lebih lanjut dijelaskan bahwa dalam percakapan yang baik akan terjadi pergantian peran antara penutur dan mitra tutur.

Peserta percakapan dalam peristiwa tutur biasanya menggunakan pasangan ujaran terdekat. Pasangan ujuaran terdekat itu terdiri dari dua ujaran. Ujaran pertama menjadi penggerak ujaran kedua. Artinya penutur mengungkapkan gagasan kemudian mitra tutur menanggapi penutur. Cook (dalam Rani, 2004:206) membedakan ujaran tanggapan menjadi dua macam yaitu ujaran yang disukai dan ujaran yang tidak disukai. Misalnya pertanyaan dapat ditanggapi dengan jawaban yang diharapkan merupakan jawaban yang disukai atau jawaban yang tidak diharapkan merupakan jawaban yang tidak disukai.

Richard dan Schmidt (dalam Rusminto, 2015:112) berpendapat bahwa peralihan tutur berkaitan dengan pencalonan topik yang akan dibicarakan. Peraliahn tutur terjadi jika ada salah satu percakapan mendukung sebuah topik, memperluas topik, mengantarkan topik baru, atau mengganti topik yang sedang dibicarakan. Lebih lanjut Rusminto (2015:112-115) menjelaskan bahwa cara mengambil giliran bicara dapat dilakukan dengan cara memperoleh, mencuri, merebut, mengganti, menciptakan, dan melanjutkan. Pengambilan giliran bivcara dengan cara memperoleh biasanya dilakukan mitra tutur setelah pembicara memberi kesempatan kepada mitra tutur untuk berbicara. Pengambilan giliran bicara menacuri dilakukan nitra tutur saat penutur sebelumnya belum selesai berbiccara. Pengambilan giliran bicara dengan cara merebut biasanya dilakukan oleh pembicara ketika belum saatnya berbicara tetapi pembicara merebut giliran orang lain. Dalam giliran bicara menciptakan penutur menciptakan tuturan baru. Pengambilan giliran bicarara melanjutkan biasanya terjadi ketika pembicara sudah memberi kesempatan mitra tutur berbicara tetaoi mitra tutur tidak mengambil kesempatan berbicara.

\section{METODE PENELITIAN}

Penelitian ini merupakan penelitian deskriptif kualitatif. Metode pengumpulan data dalam penelitian ini adalah metode simak yaitu menyimak naskah drama First Love karya Inggrida Wisnu S. Sumber data diperoleh secara online. Data yang diperoleh 
dalam penelitian ini berupa penggalan percakapan. Selanjutnya data dianalisis dengan menggunakan pola alih tutur.

\section{HASIL DAN PEMBAHASAN}

Berdasarkan hasil penelitian pola alih tutur berdasarkan pasangan ujaran terdekat yang terdapat dalam naskah drama First Love adalah sebagai berikut.

\section{Tanya Diikuti Jawab}

Dalam naskah drama tanya diikuti jawab merupakan pasangan yang doninan.

Contoh (1)

Suster Desca : "Aduh...”*terjatuh* (T1)

Dokter Nugi : : "Kamu tidak apa-apa?" (T2)

Suster Desca : "eh... tidak apa-apa, Dok." (T3)

Konteks: percakapan (1) terjadi ketika Dokter Nugi menuju ruangan dokter.

Pada waktu berjalan dia bertabrakan dengan Suster Desca. Suster Desca terjatuh dan mengatakan aduh. Dokter Nugi bertanya kepada Suster Desca mengenai kondisinya setelah terjatuh.

Suster Desca sebagai penutur dalam T1 menuturkan aduh karena dia terjatuh setelah bertabrakan dengan Dokter Nugi. Tuturan tersebut direspon oleh Dokter Nugi dengan T2 dengan cara bertanya kepada Suster kamu tidak apa-apa? Selanjutnya T2 direspon oleh Suster Desca dengan jawaban eh... tidak apa-apa, Dok.

\section{Salam Diikuti Salam}

Salam diikuti salam ditemukan dalam naskah drama terutama pada saat penutur bertemu dengan mitra tutur untuk memulai percakapan.

Contoh (2)

Suster Desca : "Selamat siang..." (T1)

Selly : "Siang.. Anda Suster baru ya?" (T2)

Konteks: percakapan ini terjadi antara Selly dengan Suster Desca di ruang rawat inap. Mula-mula yang membantu Dokter Nugi untuk merawat Selly yaitu Suster Amanda. Akan tetapi, Suster Amanda harus pindah tugas di ruangan lain sehingga tugasnya digantikan oleh Suster Desca.

Dalam contoh (2) Suster Desca sebagai penutur memberi salam kepada pasien barunya Selly dengan T1. Tuturan tersebut direspon dengan salam oleh Selly sebagai mitra tutur dengan T2. Akan tetapi, dalam T2 Selly juga merespon dengan pertanyaan karena yang 
datang bukan Suster Amanda tetapi suster baru. Jadi, dalam contoh (2) salam dijawab dengan salam kemudian dilanjutkan dengan pertanyaan.

\section{Panggilan Diikuti Perintah, dan Jawaban}

Dalam wacana percakapan biasanya panggilan langsung diikuti jawaban. Namun, dalam naskah drama ni ditemukan paggilan diikuti perintah kemudian jawaban.

Contoh (3)

Selly : "Ibu....." (T1)

Dokter Nugi : "Panggil ibunya!" (T2)

Ibu Selly :"Iya nak.. Ibu disini..” (T3)

Konteks: percakapan ini terjadi antara Selly, Dokter Nugi, dan Suster Desca di kamar Selly. Dalam kondisi kritis Selly memanggil ibunya. Mendengar Selly memanggilI bunya, Dokter Nugi langsung menyuruh Suster Desca memanggil Ibu Selly.

Selly sebagai penutur dalam kondisi kritis memanggil ibunya. Hal tersebut dapat dilihat dalam T1. T1 kemudian direspon oleh mitra tutur (Dokter Nugi) menyuruh Suster memanggil Ibu Selly yang terdapat dalam T1. . Kemudian tuturan T1 baru direspon oleh Ibu Selly dengan tuturan T3. Jadi, dalam contoh (4) pangilan direspon dengan perintah kemudian direspon dengan jawaban.

\section{Salam Pisah Diikuti Pesan}

Salam pisah ditemukan pada saat penutur meninggalkan mitra utur.

Contoh (4)

Ibu Desca $\quad$ :... Ibu takut hal ini terjadi lagi,tolong jaga Desca ya" mengelus kepala Nugi*

Nugi Kecil : "Iya bibi.. Nugi harus pulang ya. Selamat malam" *tersipu malu* (T1)

Ibu Desca : : Hati-hati di jalan ya, Nak...” (T2)

Konteks: percakapan ini terjadi di rumah Desca antara Ibu Desca dengan Nugi kecil. Nugi Kecil menemukan Desca kecil tersesat di jalan kemudian Nugi kecil mengantarkannya pulang.

Dalam contoh (4) Nugi Kecil sebagai penutur menuturkan bahwa ia harus pulang (T1) .

Oleh karena itu, Nugi Kecil mengucapkan selamat malam kepada Ibu Desca dalam T1.

Tuturan Nugi direspon oleh Ibu Desca dengan pesan hati-hati di jalan Nak dalam (T2).

Jadi, contoh (4) salam pisah dijawab dengan pesan.

\section{Pujian Diikuti Penolakan}

Dalam percakapan penutur terkadang memuji mitra tutur. Hal tersebut dapat dilihat dalam contoh berikut ini. 
Contoh (5)

Selly : “... saya Selly. Suster cantik ya!” (T1) (pujian)

Suster Desca : "Ah kamu bisa saja! (T2) (penolakan)

Konteks: percakapan ini terjadi antara Selly dan Suster Dessca ketika pertama kali mereka bertemu. Sustes Desca mengantikan Suster Amanda karena pindah tugas ke ruangan lain.

Selly sebagai penutur memuji suster Desca yang baru saja masuk ke kamar Selly. Dia memuji kecantikan suster Desca dengan tuturan T1. Hal tersebut dilakukan karena menyenangkan hati mitra tutur. T1 direspon oleh mitra tutur (Suster Desca) dengan penolakan dengan jawaban ah kamu bisa saja dalam tuturan T2.

\section{Menawari Diikuti Memuji dan Menerima}

Dalam percakapan biasanya tawaran diikuti dengan penerimaan. Akan tetapi dalan percakapan berikut ini menawari diikuti memuji baru menerima.

Contoh (6)

Suster Mei : : "Oh iya! Saya punya ide! Gimana kalau kita tukar obatnya dengan racun?" (T1) (menawari)

Suster Amanda ;"Bener tuh! Kamu pintar, Mei!” (T2) (memuji)

Suster Zae : : "Ya sudah, cepat kita ke ruangan obat. Sebelum apoteker datang!" (T3) (menerima)

Suster Mei : “Ayo!!” (T4) (menerima)

Konteks: Dokter Nugi sedang menemani Selly di halaman rumah sakit. Suster Amanda, Suster Zae dan Suster Mei melihat mereka dari kejauhan. Mereka tidak menyukai Selly. Mereka berencana membuhnuh Selly dengan cara mnukar obat Selly dengan racun.

Suster Mei sebagai penutur menawarkan idenya untuk membunuh selly dengan cara menukar obat Selly dengan racun. Hal tersebut terdapat dalam T1. T1 direspon oleh mitra tutur (Suster Amanda) dengan T2 menerima dengan mengatakan bener tuh sekaligus memuji ide Suster Mei dengan tuturan kamu pintar. Mei .Begitu juga dengan suster Zae menerima ide Suster Mei dengan tuturan T3 ya sudah.. berarti 'setuju'.

\section{Mengeluh Diikuti Bertanya, Menjawab, Menawari, dan Menolak}

Contoh (7)

Suster Desca : "Aduh..." *terjatuh* (T1) (mengeluh)

Dokter Nugi : "Kamu tidak apa-apa?" (T2) (bertanya)

Suster Desca : "eh... tidak apa-apa, Dok." (T3) (jawaban)

Dokter Nugi : :Mari saya bantu.." (T4) (menawarkan)

Suster Desca : "Tidak, tidak usah dok. Saya permisi dulu.." (T5) (menolak) Konteks: percakapan ini terjadi antara Suster desca dengan Dokter Nugi. Ketika menuju ruangan dokter, Dokter Nugi bertabrakan dengan Suster Desca 
Dalam contoh (7) Suster Desca sebagai penutur mengeluh aduh dalam T1 sehingga direspon oleh mitra tutur (Dokter Nugi) dengan pertanyaan kamu tidak apa-apa dengan T2. T2 kemudian dijawab dengan tuturan T3. Dokter Nugi menawarkan bantuan kepada suster Desca dengan tuturan T4 akan tetapi ditolak dengan tuturan T5

\section{Menuduh Diikuti Menolak dan Mengakui}

Contoh (8)

Selly

: “Kenapa dok? Kok melamun gitu? Suka ya sama suster barunya?"(T1) (menuduh)

Dokter Nugi :Hah? Tidak.(T2) (menolak) Saya hanya suka sama kamu!" (mengakui)

Selly : : *kaget* “Apa?” (T3)

Dokter Nugi : "Iya, saya hanya suka sama kamu. Saya akan menemani kamu sampai kapanpun!" (T4) (mengakui)

Konteks: percakapan ini terjadi di kamar Selly antara Selly dan Dokter Nugi. Mula-mula Suster Desca di kamar Selly. Setelah Dokter Nugi datang Suster Desca minta izin keluar ruangan. Dokter Nugi melamun setelah Suster Desca keluar.

Selly sebagai penutur menanyakan pada Dokter Nugi dengan T1. Dalam T1 meskipun Selly menggunakan kalimat tanya namun hal tersebut merupakan tuduhan karena sebelumnya Dokter Nugi sudah memberi bunga kepada Selly. Jadi, hal ini merupakan tuduhan Selly kepada Dokter Nugi. Dokter Nugi merespon T1 dan penolakan kemudian dilanjutkan dengan mengakui hal tersebut terdapat dalam T2 dan T4.

\section{Permohonan diikuti Perjanjian, Permohonan, Penangguhan, Permohonan,}

\section{Pengabulan}

Contoh (9)

Ibu Selly

: “... Saya boleh meminta sesuatu kepada dokter?” (T1) (permohonan izin)

Dokter Nugi : "Selama saya bisa, saya akan lakukan" (T2) (persyaratan)

Ibu Selly : :Saya ingin dokter menemani Selly sampai akhir hayatnya. Saya ingin melihat dia bahagia, Dok. Saya lihat jika Dokter berada disamping Selly, dia selalu tersenyum.."(T3) (permohonan)

Dokter Nugi : "Tapi, Bu....”(T4) (penangguhan)

Ibu Selly : :Saya mohon dok.. ini permintaan saya yang terakhir!”(T5) (permohonan)

Dokter Nugi : :*Termenung* "Baiklah...." (T6) (pengabulan)

Konteks: percakapan ini terjadi antara Ibu Selly sebagai penutur dan Dokter Nugi sebagai mitra tutur. Ibu Selly mohon agar Dokter Nugi mau menemai Selly sampai akhir hayatnya. 
Ibu Selly sebagai penutur memohon sesuatu kepada Dokter Nugi. Hal tersebut terdapat dalam T1. Dokter Nugi merespon T1 dengan tuturan T2 yang berisi persyaratan. Ibu Selly merespon T2 dengan tuturan yang berisi permohonan kepada Dokter Nugi untuk menemani Selly hingga akhir hayatnya yang dapat dilihat dalam T3. T3 direspon oleh Dokter nugi dengan penangguhan. Karena Dokter Nugi menangguhkan permohonan ibu Selly akhirnya ia mohon kembali dan mengatakan bahwa itu permintaan terkhirnya. Hal tersebut terdapat dalam T5. Selanjutnya T5 direspon oleh Dokter Nugi dengan pengabulan.

\section{Cara Mengambil Giliran Bicara}

Berdasarkan hasil penelitian pengambilan giliran bicara dalam drama First Love karya Inggrida Wisnu S menggunakan cara memperoleh, mencuri, menciptakan, melanjutkan, dan merebut.

\section{Memperoleh}

Giliran bicara memperoleh merupakan giliran bicara yang diberikan oleh penutur kepada mitra tutur setelah penutur selesai menyampaikan tuturannya.

Contoh (10)

Dokter Nugi : : "Selamat pagi, Bu.."

Ibu Selly : : "Pagi, Dok.. Ada perkembangan apa dengan Selly?"

Dokter Nugi : "mohon maaf, bu. Semakin hari kesehatannya menurun drastis. Harapan hidup anak ibu sangat kecil sekali. Kita berdoa saja semoga ada keajaiban yang bisa menolongnya."

Ibu Selly : : "Dok, tolong anak saya... selamatkan dia, Dok. Berapapun biayanya akan saya berikan asal anak saya bisa hidup bahagia.." menangis*

Dokter Nugi : "Segala upaya akan kami lakukan demi anak ibu. Tolong yang sabar ya, Bu."

Ibu Selly : : *mengangguk*

Dokter Nugi : :Ya sudah saya mau memeriksa perkembangan anak ibu dulu ya. Permisi.."

Ibu Selly : :Baik, Dok."

Percakapan di atas merupakan percakapan antara Dokter Nugi sebagai penutur dan Ibu Selly sebagai mitra tutur. Percakapan mereka seperti biasanya diawali dengan salam oleh penutur kemudian direspon dengan salam oleh mitra tutur. Giliran bicara diperoleh dengan cara memperoleh yaitu setelah penutur selesai baru mitra tuturnya berbicara. 


\section{Mencuri}

Giliran bicara mencuri diperoleh dengan cara mitra tutur mengambil alih giliran bicara tetapi pembicara sebelumnya belum selesai berbicara.

\section{Contoh (11)}

\begin{tabular}{|c|c|}
\hline Suster Mei & : “Gimana kalau kita bunuh aja pasien itu?” \\
\hline Suster Zae & $\begin{array}{l}\text { : "Apa kamu gila? Nanti kalau kita ketahuan, kita bisa } \\
\text { dipenjara!" }\end{array}$ \\
\hline Suster Mei & $\begin{array}{l}\text { : "Ya engga lah! Membunuhnya juga pake cara yang halus } \\
\text { dong! Jangan sampai ketahuan!" }\end{array}$ \\
\hline Suster Amanda & : "Bener juga tuh!" \\
\hline Suster Zae & :"Ih kalian bener-bener gila!" \\
\hline Suster Mei & :"Udah kamu diem aja. Kita lihat besok!” \\
\hline Suster Amanda & $\begin{array}{l}\text { :"Kita pikirkan dulu bagaimana caranya. Besok kita lakukan } \\
\text { rencana kita.." }\end{array}$ \\
\hline Dokter Lana & $\begin{array}{l}\text { : "Heh! Ada apa ini! Bukannya menjalankan tugas malah } \\
\text { bergosip!" }\end{array}$ \\
\hline Suster Mei & : “Eh, Dokter Lana. Tidak, kami tidak bergosip!” \\
\hline Dokter Lana & : "Lalu apa?" \\
\hline Suster Amanda & : "Eh....." \\
\hline Konteks: perca & $\begin{array}{l}\text { pan ini terjadi antara Suster Mei, Suster Zae dan Suster } \\
\text { berencana untuk membunuh Selly. Ketika mereka sedang }\end{array}$ \\
\hline
\end{tabular}

Cara memperoleh giliran bicara dalam contoh (8) menunjukkan bahwa tuturan Dokter lana merupakan tuturan yang terjadi dengan alih tutur mencuri. Tuturan Dokter Lana terjadi saat Suster Mei, Suster Zae, dan suster Amanda sedang berencana membunuh Selly. Ketika mereka sedang mendiskusikan rencananya tersebut tiba-tiba datang Dokter Lana mengatakan "Heh! Ada apa ini! Bukannya menjalankan tugas malah bergosip!'’Tuturan tersebut diucapkann ketika Suster Amanda belum berhenti berbicara.

\section{Menciptakan}

Cara mengambil giliran bicara menciptakan merupakan cara mengambil giliran bicara dengan cara mitra tutur menciptakan tuturan baru dengan tuturan sebelumnya. Dengan kata lain penutur mengalihkan tema pembicaraan.

Contoh (12)

Dokter Nugi : :"Selamat siang, Selly. Ini buat....."

Selly : :"Siang, dok. Ada apa dok? Ini suster Descsa."

Dokter Nugi : "tidak apa-apa. Ini buatmu. Suster Desca? Oh, saya dokter Nugi." 
Suster Desca $\quad$ :"Dokter Nugi? Oh iya, senang bisa berkenalan dengan Anda. Mulai saat ini saya yang menggantikan Suster Amanda. Mohon bantuannya!"

Dokter Nugi : :"Hmm.. Baik.."

Suster Desca : : "Ya sudah, saya permisi dulu ya..

Dokter Nugi : :Ya,silahkan.."

Konteks: Suster Desca sedang berada di kamar Selly. Ketika mereka sedang berada di kamar datanglah Dokter Nugi membawa bunga untuk Selly.

Contoh (12) menunjukkan bahwa Selly menciptakan tuturan baru sebagai respon tuturan Dokter Nugi yang membawa bunga untuknya. Selly mengalihkan tema pembicaran karena di situ ada Suster Desca. Tema pembicaraan semula Dokter Nugi memberi bunga Selly. Akan tetapi, Selly mengalihkan pembicaraan dengan memperkenalkan Suster Desca kepada Dokter Nugi.

\section{Melanjutkan}

Cara mengambil giliran bicara dengan melanjutkan merupakan cara pengambilan giliran bicara karena mitra tutur tidak memanfaatkan kesempatan yang diberikan penutur sehingga penutur melanjutkan tuturannya.

Contoh (13)

Nugi kecil : : :Hey! Kenapa kamu menangis?"

Desca Kecil : *tidak menjawab**menangis semakin kencang*

Nugi kecil : "dasar anak aneh! Yasudah aku mau pulang saja!"

Konteks: Pada suatu hari, seorang gadis kecil sedang bermain di taman. Namun, ketika menjelang senja ia kebingungan. Ia tidak tahu arah jalan pulang dan akhirnya tersesat. Dia menangis di pinggiran jalan. Kemudian ada seorang anak laki-laki yang menegurnya.

Contoh (13) Nugi kecil sebagai penutur bertanya pada Desca kecil yang sedang menangis dipinggir jalan. Mitra turtur (Desca Kecil) tidak menjawab pertanyaan Nugi. Respon yang diberikan Desca menangis semakin kencang. Petanyaan tidak dijawab kemudian Nugi melanjutkan dasar anak aneh! Ya sudah aku mau pulang saja!'Pengambilan giliran bicara dengan cara melanjutkan ini karena penutur sudah memberi kesempatan berbicara kepada mitra tutur tetapi kesempatan yang diberikan tidak digunakan.

\section{Merebut}

Merebut merupakan cara mengambil alih giliran bicara pada saat penutur terdahulu sedang berbicara dan masih ingin melanjutkannya, tetapi mitra tutur langsung berbicara.

Contoh (14) 


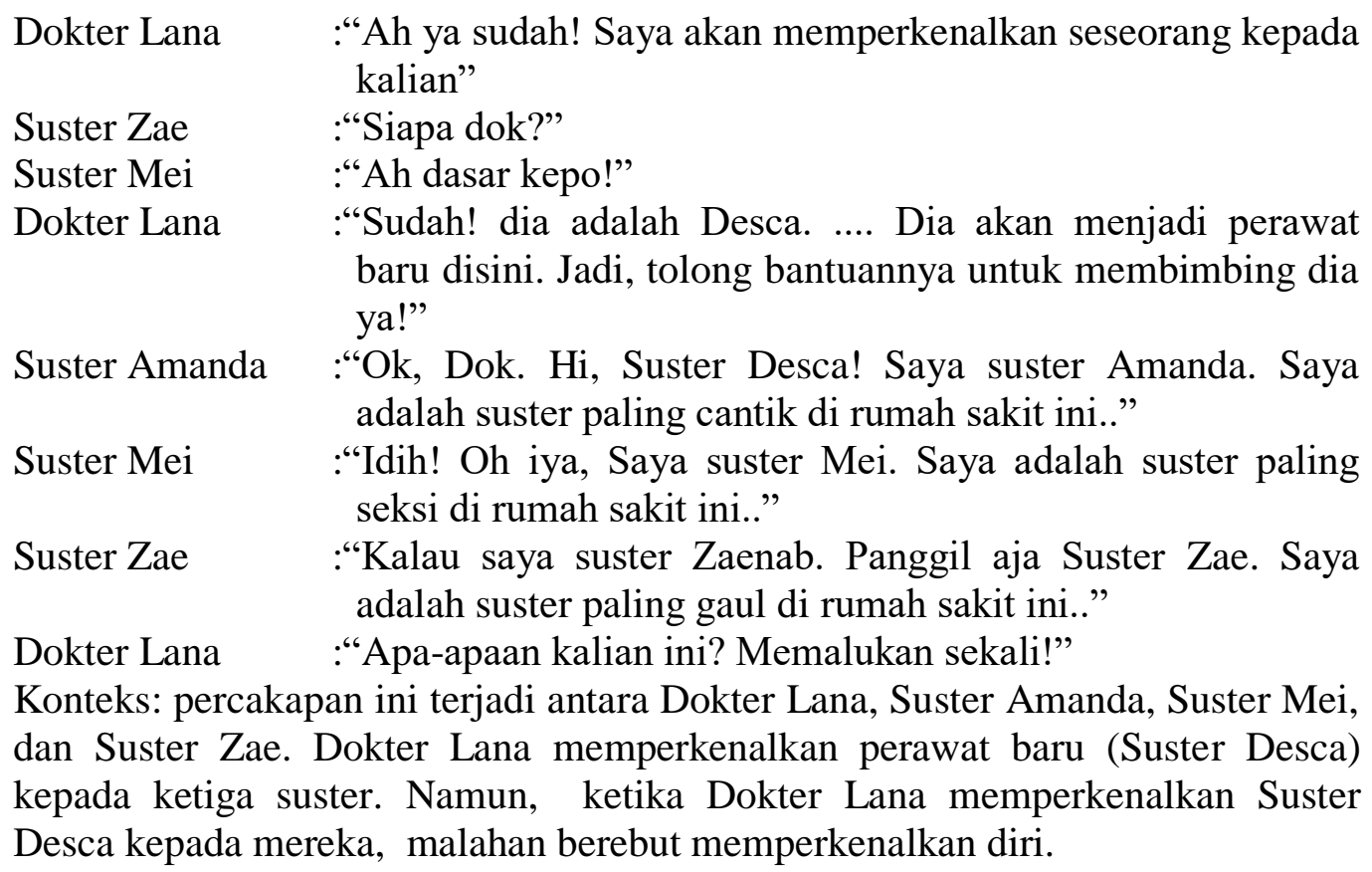

Contoh (11) menunjukkan bahwa pergantian tutur dari Suster Amanda ke Suster Mei ke Suster Zae terjadi dengan acara merebut. Mereka sangat antusias memperkenalkan dirinya kepada Suster Desca. Mereka memperkenal diri dengan cara yang tidak sopan (berebut) sehingga Dokter Lana mengingatkan mereka. "apa-apaan kalian ini? Memalukan sekali!"

\section{SIMPULAN}

Berdasarkan hasil penelitian pola alih tutur berdasarkan pasangan ujaran terdekat yang terdapat dalam naskah drama First Love adalah (1) pertanyaan diikuti jawaban, (2) salam diikuti salam, (3) panggilan diikuti jawaban, (4) salam pisah diikuti pesan, (5) pujian diikuti penolakan, (6) menawari diikuti memuji dan menerima, (7) mengeluh diikuti bertanya, menjawab, menawari, dan menolak, (8) menuduh diikuti menolak dan mengakui (9) permohonan diikuti perjanjian, permohonan, penangguhan, permohonan, pengabulan. Adapun pengambilan giliran bicara dalam drama First Love karya Inggrida Wisnu S menggungunan cara memperoleh, mencuri, menciptakan, melanjutkan, dan merebut. 


\section{DAFTAR PUSTAKA}

Pusat Bahasa Departemen Pendidikan Nasional. 2007. Kamus Besar Bahasa Indonesia. Jakarta: Balai Pustaka

Rani, Abdul, Bustanul Arifin, dan Martutik.2004 Analisis Wacana sebuah Kajian Pemakaian, Malang: Bayu Media

Rusminto, Nurlaksana Eko. 2015. Analisis Wacana Kajian Teoritis dan Praktis. Yogyakarta:Graha Ilmu.

Suroso. 2015. Drama: Teori dan Praktik Pementasan. Yogyakarta: Allmatera.

\section{Sumber data}

Wisnu S, Inggrida. 2013 First Love http://inggridawisnu. blogspot.co.id/2013/03/ naskah-drama-indonesia-cinta-pertama.html diunduh 29 April 2018 